\title{
CREATIVE REUSE OF FORMER DEFENCE FACILITIES IN THE UNITED STATES
}

\author{
C. PREBLE \\ Cato Institute, USA.
}

\begin{abstract}
Although many people often worry that the closure of military facilities will seriously harm local economies, most areas eventually recover the lost. Case studies paint a richer picture than statistics. This article explores three cases from the United States - The Tredegar Iron Works in Richmond, Virginia; the Springfield Armory in Springfield, Massachusetts; and the Brunswick Naval Air Station in Brunswick, Maine - to show how communities have adapted to the closure of military facilities.

Keywords: Brunswick Naval Air Station, defence conversion, Maine, Massachusetts, Richmond, Springfield Armory, Tredegar Iron Works, Virginia.
\end{abstract}

\section{INTRODUCTION}

Community leaders and politicians often worry that the closure of military facilities will do irreparable harm to their economies. Empirical data shows that most areas recover lost jobs within a matter of time, but case studies paint a richer picture than statistics. This article explores three distinct cases - The Tredegar Iron Works in Richmond, Virginia; the Springfield Armory in Springfield, Massachusetts; and the Brunswick Naval Air Station in Brunswick, Maine. This paper shows how different communities have adapted to the loss of military industry and jobs. Although the timing for redevelopment and reuse varies, all three properties have experienced a rebirth by transitioning to civilian uses.

\section{RICHMOND}

Richmond, the state capitol of Virginia, is perhaps best known as the one-time capitol of the Confederacy during the American Civil War [1]. On 4 April 1865, one day after the city fell to Union forces [2], President Abraham Lincoln toured the devastation and met with civic leaders. Among the Richmond elite who met with Lincoln that day was Joseph Anderson, owner and operator of the Tredegar Iron Works [3].

It is hard to exaggerate Tredegar's significance to Richmond during the antebellum years, and to the Confederacy during the war [4]. It was arguably the only arms maker in the Confederacy. Before the famed assault on Charleston's Fort Sumter, Tredegar delivered cannons, mortars and ammunition to the secessionist forces in South Carolina [3]. A Tredegar-made 10-inch mortar fired the first shot of the war, on 15 April 1861 [4].

Most accounts of Tredegar revolve around these relevant facts and anecdotes. Tredegar was the 'iron maker to the Confederacy' and, as far as most historical works are concerned, there the story ends.

Except that it doesn't. Anderson managed to save Tredegar. The company provided the iron products that the South needed to rebuild [2]. It also continued to make munitions, supplying

This paper is part of the Proceedings of the 3rd International Conference on Defence Sites: Heritage and Future (Defence Heritage 2016)

www.witconferences.com
} 


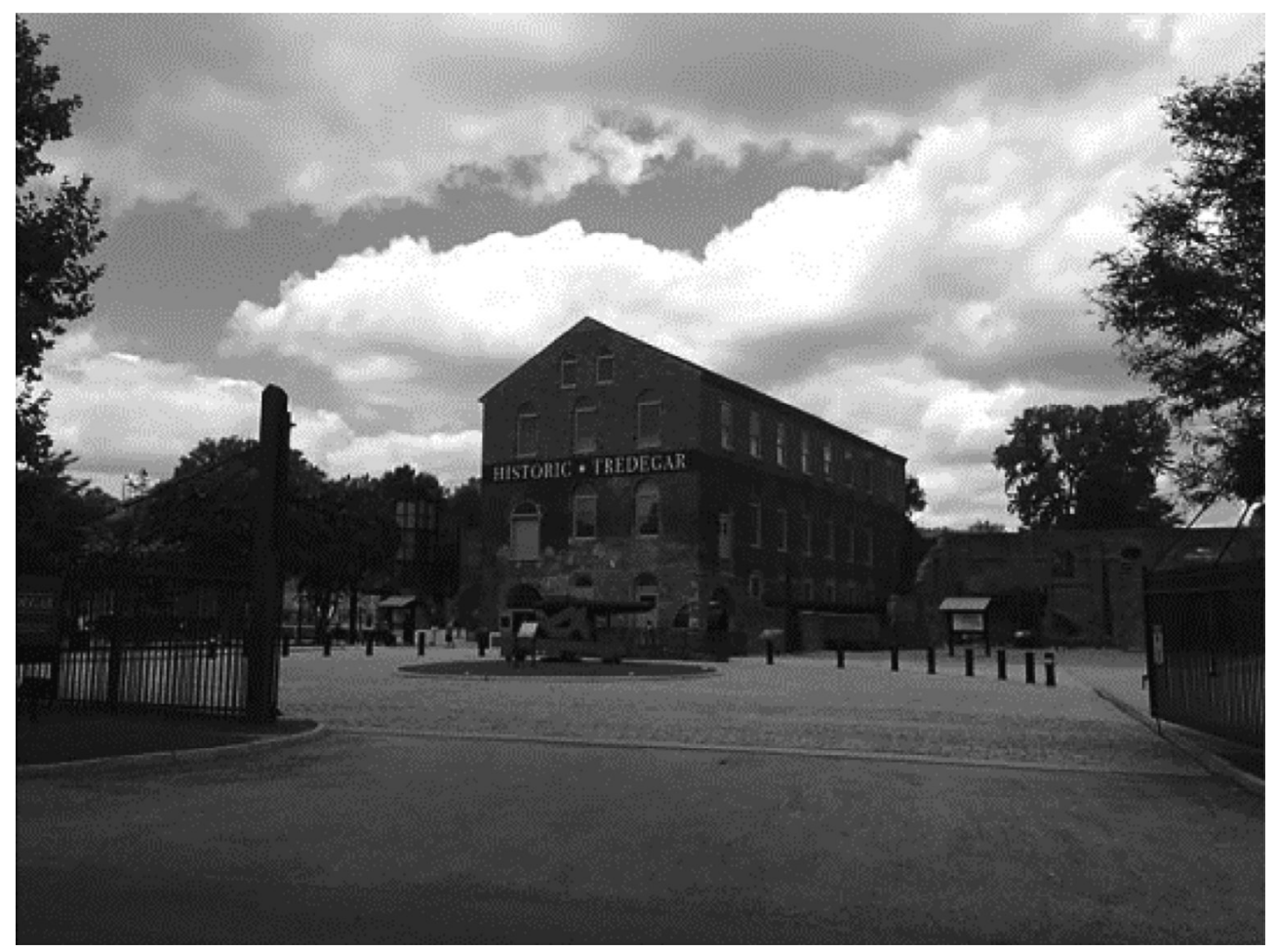

Figure 1: The Civil War Visitor Center at Tredegar. Image by C. Preble.

the US military as late as the Korean War in the early 1950s [3]. It didn't close its doors for good until 1957 [4].

After languishing for decades as an abandoned industrial site, the property has now been transformed into a museum and a public park on the banks of James River, as pictured in Figs. 1 and 2. And the surrounding neighbourhood has been transformed with it.

\subsection{History of Tredegar Iron Works}

Tredegar Iron Works was founded in 1836 by Francis B. Deane, a 23-year-old furnace operator [4]. The company took its name from the Tredegar Iron Works in Wales, where another early employee had trained as an engineer [4].

In 1841, Deane hired Joseph R. Anderson to be his commercial agent [5]. By 1848, Anderson had purchased the company outright. A West Point graduate, Anderson applied his engineering and military training to revolutionize Tredegar's business [6]. He diversified Tredegar's product line from small, simple items, such as nails and chains, to large and complex manufacturing, including steamships and rail cars [6]. He secured contracts to provide the US Navy with chains, cables and munitions [4]. He also drove down Tredegar's costs by employing a large slave labour force. When white workers objected, Anderson fired them, and brought in more slaves [6]. By 1860, Tredegar was a sprawling facility, comprising 4 rolling mills, 14 foundries and machine shops, a nail factory, 6 shops specializing in 
the manufacture of iron rails, plus 2 circular saw works and sundry other smaller iron and metal works [6].

Anderson, an ardent secessionist, was commissioned as a brigadier general in the Confederate army [4], and the governor of Virginia established a special 'Tredegar Battalion' to protect one of the state's most precious assets [6].

During the course of the war, Tredegar manufactured iron plates for warships [7], a special armoured rail car, complete with a mounted cannon [6], and enormous quantities of cannons, shells and ammunition of various types. Employment jumped from 750 at the start of the war to 2,500 by 1863 .

The additional manpower couldn't make up for the shortage of raw materials, however, especially iron ore [4]. The plant operated at about one-third its total capacity, and even shut down temporarily in March 1863 [7]. A series of fires eventually led to the collapse of the entire foundry building and substantial damage to other properties on the site [8]. But Tredegar survived. After the war, President Andrew Johnson pardoned Anderson for supporting the confederacy, and the company resumed operations under his direction in August 1865 [2].

Anderson formed a joint stock company in 1866 to raise the capital needed to upgrade and expand Tredegar's production facilities [2]. The company focused especially on manufacturing iron rails to meet the demand fuelled by the rapid growth of railroads after the war [2]. Later, when steel rails displaced iron ones, Anderson adapted by diversifying into other products, including spikes, nails and wheels [2]. Tredegar stopped making rails entirely in 1870,

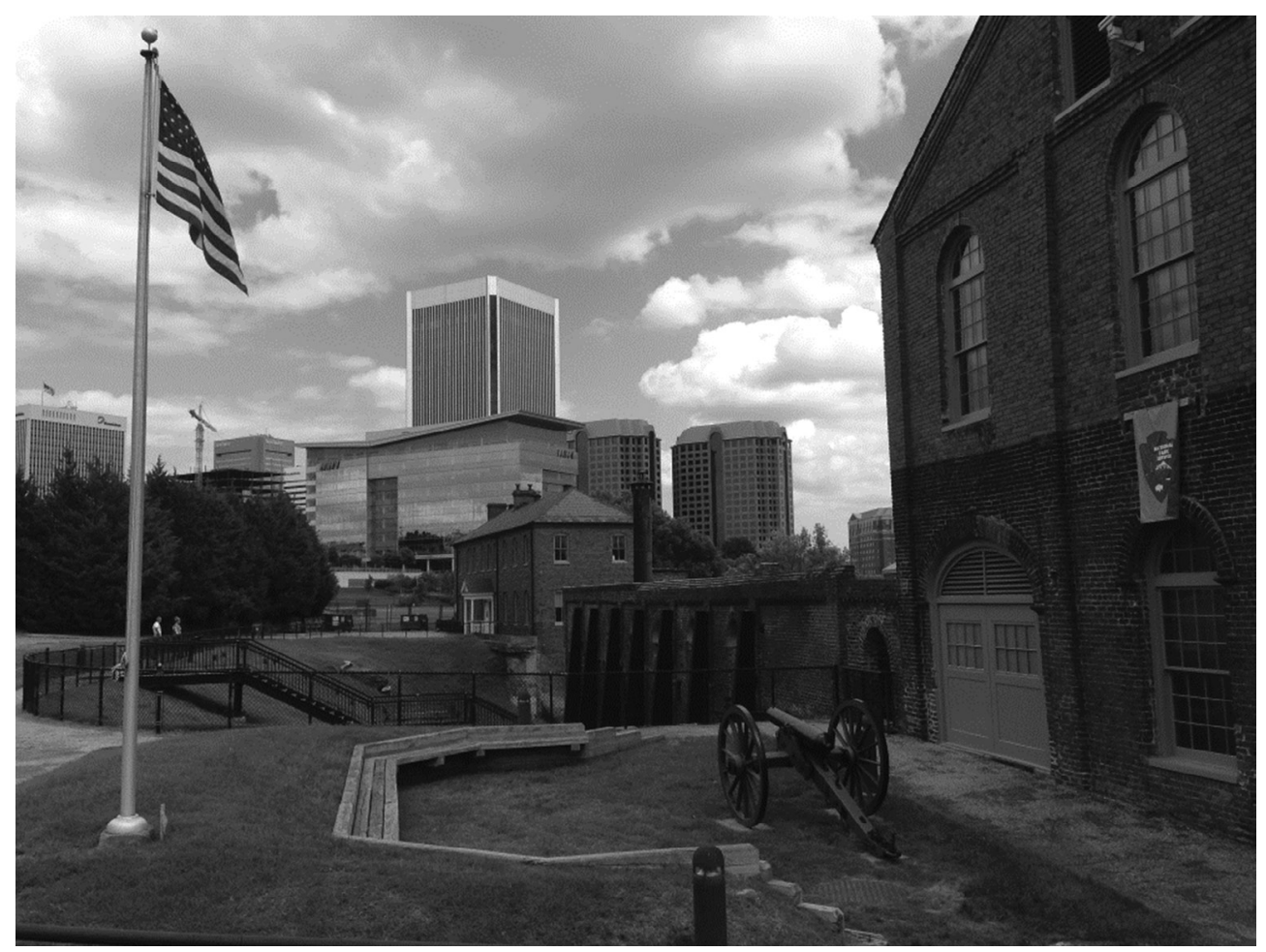

Figure 2: Historic Tredegar with downtown Richmond in the background. Image by C. Preble. 
and by 1872 it was producing 50,000 tonnes of iron in a single year, five times its levels before the war. Employment rose to nearly 1,000 [2].

The Panic of 1873 devastated the railroads [9], and Tredegar emerged from the panic with over \$1 million in debt [2]. It remained an important employer in Richmond, however, and was at the heart of the Oregon Hill neighbourhood that grew up around the plant during the 19 th century.

\subsection{Ethyl, NewMarket and the revival of the Richmond riverfront}

But the forges eventually went cold. Anderson's family continued to operate the company after his death in 1892 [4], ultimately selling the property to the Ethyl Corporation in 1957 [4]. At the time, only four buildings were still standing. Five years later, the property came under new ownership, when the Albemarle Paper Company purchased Ethyl, and adopted its name. Albemarle's CEO, F.D. Gottwald, executed a series of other acquisitions and buyouts in the 1960s and 1970s, transforming Ethyl into a major manufacturer [10].

Ethyl focused on cleaning up the neighbourhood in and around Oregon Hill, and along the banks of the James. In the 1970s, it concentrated on preserving and restoring the four surviving structures from Tredegar, beginning with the Pattern Storage Building, and the Foundry [11]. It later turned its attention to the Carpenter Shop and the Company Store. The company hoped to eventually find uses that honoured the property's historical significance [11].

Since 2000, the company has subleased space to the National Park Service, which operates the Civil War Visitor Center at Tredegar [5, 11]. In 2006, the American Civil War Museum opened in the old cannon foundry [5], and in 2013 it merged with the Museum of the Confederacy [12]. The construction of a new 40,000 square foot space promised to benefit both parties: more artefacts in a single location, and in one of Richmond's most historic properties [12].

The expansion and relaunch of the new museum coincides with a dramatic revival of the Richmond riverfront. Ethyl, which changed its name to NewMarket Corporation in 2004, is a leading partner in the Richmond Riverfront Development Corporation, and has allocated a large portion of their real estate holdings near and along the riverfront for future development [13]. A three-acre parcel, to be called Tredegar Green, will connect the Virginia War Memorial at 2nd Street to the Tredegar site on James River [13], allowing convenient access for pedestrians wishing to access nearby Belle Isle and Brown's Island. Considerable parking space allows for other recreational uses, including kayak tours on the James [13].

When I visited the area in July 2013, I was struck by the idyllic beauty of the river and the open space, just a few hundred yards from some of the city's most famous tenants, including the Federal Reserve Bank of Richmond. NewMarket's sprawling campus, including three buildings at the corner of E. Byrd and S. 2nd Street, is separated from the old Tredegar site by Gambles Hill Park, and is just across the street from the Virginia War Memorial. The tidy row houses and town homes in the Oregon Hill neighbourhood, once home to forge workers and machinists, have a spectacular view of James River, and are within close proximity to downtown Richmond.

Joseph Anderson would hardly recognize it, but Tredegar lives on.

\section{SPRINGFIELD}

Basketball fans may know Springfield, Massachusetts, as the birthplace of the sport. But more than 100 years before James Naismith hung two peach baskets on opposite walls in a school gymnasium, Springfield was known for something else: guns. 
Established during the Revolutionary War as a storehouse for weapons and ammunition, the Springfield Armory quickly became the pre-eminent small arms maker for the US government. But in the early 1960s the Pentagon reasoned that private arms makers could do the work just as well, and at lower cost. The Armory officially closed on 30 April 1968 [14].

Almost immediately, officials sought ways to repurpose the site. Several of these enterprises were successful, including a technical college and a public park. But the broader economic trends in western Massachusetts and beyond made it difficult to sustain a new manufacturing base that could replace the jobs and wages lost when the Armory closed.

\subsection{The Springfield Armory: history}

During the American Revolutionary War, Springfield was a storage facility for weapons and ammunition for the Continental Army [15] and later a rudimentary weapons laboratory [16]. After the war, in 1789, George Washington had personally inspected Springfield, and in 1794 , the new federal government authorized the construction of a national armoury there, as well as a second in Harpers Ferry, Virginia [17].

Over the years, the two armouries adopted new technologies to boost productivity, but Springfield eventually gained the upper hand. Springfield perfected the use of interchangeable parts and, by the mid-1820s, the Armory had a fully mechanized weapons production line, the first of its kind in the United States [17]. Later, Springfield moved from water to steam power, allowing it to again greatly expand its output.

A method that became known as the 'Armory Practice' made it all possible. Production at the Armory was checked through a series of precision gage controls [17]. The process was intensive and exacting, but also expensive.

During the early months of the American Civil War, after Confederate forces destroyed the armoury at Harpers Ferry, Springfield swiftly ramped up production to meet wartime demand. Employment rose ten-fold, to nearly 3,000, and these workers produced over 800,000 riflemuskets during the war [16].

In the latter half of the 19th century, private manufacturers began to compete with the Armory's designs. Springfield responded with the Model 1903, which firearms expert and historian Philip Sharpe called 'the finest and most precision-built piece of machinery any military organization has ever produced' [16] and later the M1 Garand, one of the finest firearms in American history. General George S. Patton called it 'The greatest battle implement ever devised', and it is still prized by professional shooters for its accuracy and reliability [18].

At the time of American entry in World War II in December 1941, there were 7,500 people working at the Armory [16]. Employment would grow to nearly double that number - 14,500 during the course of the war [15]. With this hugely expanded workforce, Springfield produced over 3.1 million rifles [17].

Employment at the Armory spiked again during the Korean War, to 7,700 workers, but production never matched the rate achieved during World War II [16]. And, after Korea, the Armory struggled to find its way.

On 2 April 1963, during the 169th anniversary of the Armory's founding, the National Park Service recognized it as a National Historic Landmark [15], that signalled, if only coincidentally, that the Armory's days were numbered. It had pioneered a series of innovations in the 19th century, and had developed some of the finest firearms of the early 20th century. But it always struggled to keep pace with private contractors. On 19 November 1964, Secretary of Defense Robert McNamara made it official: the Springfield Armory would be closed [16]. 


\subsection{The aftermath}

The community reaction to the proposed closure was swift and severe. State and local officials objected to the Pentagon's determination that the Armory was no longer essential. And they pointed out that the economic impact of the closure would be devastating for Springfield.

But, when that effort failed, community leaders soon moved to Plan B: finding suitable alternate uses for the site. City Council President Armando G. Dimauro, with perhaps a touch of wishful thinking, saw 'a great deal to be gained' from the Armory's closure because it would release 'choice land for industrial development' [15]. The Springfield Daily News ran a story under the optimistic headline 'Armory Closing May Spur Boom' [15].

This was true in at least one respect. The city had been home to a fine technical school, Springfield Technical Institute, but hundreds of applicants were turned away every year due to lack of space. In 1966, the Armory Planning Committee proposed turning some of the Armory's property into a genuine college campus that could accommodate up to 3,000 fulltime students [15].

Such plans ran afoul, however, of the Armory's status as a historic site. In order to make room for the new students, the school proposed that some of the Armory's buildings be torn down [15]. But the National Historic Preservation Act, signed into law in 1966, mandated that historic properties be preserved [15].

In the end, the new technical school, Springfield Technical Community College (STCC), opened in September 1967 inside of a few of the historic buildings [19]. It has since grown into the largest technical community college in Massachusetts.

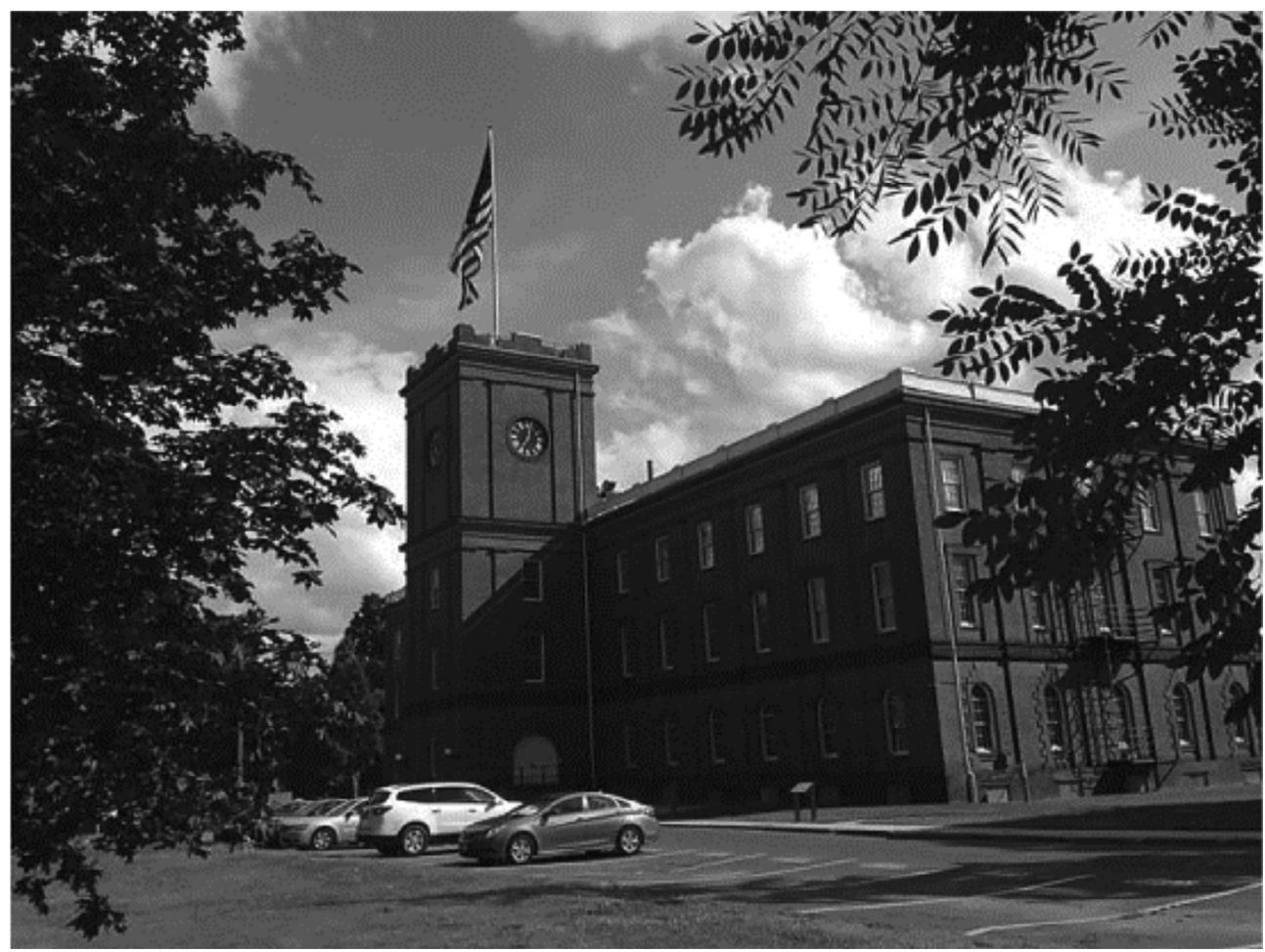

Figure 3: Springfield National Historic Site. Image by C. Preble. 


\subsection{The Armory and Springfield today}

When it closed on 30 April 1968, the Springfield Armory was the longest continuously operated industrial facility in the United States [16]. Since then, Springfield has struggled [20].

When I visited the city for the first time in July 2014, I was struck by the apparent peaceful coexistence of STCC and the National Historic Site, although I was certainly aware of the past battles over the preservation or redevelopment. The conditions elsewhere, in the community surrounding the former Armory site, and in the downtown area known as Court Square, seem fairly typical of former manufacturing cities in the American northeast. In 2007, just $12.5 \%$ of the city's residents were employed in manufacturing [20].

The Springfield Armory National Historic Site (pictured in Fig. 3) on one end of Armory Square is in good condition, and houses an interesting collection of mostly static displays telling the story of the Armory, though I saw only a handful of other visitors during my time there.

The STCC, meanwhile, is a vibrant learning community occupying new classroom buildings and several of the original Armory structures, including the Armory Administrative building at the opposite end of Armory Square from the National Park Service site.

\section{BRUNSWICK}

The small coastal town of Brunswick, Maine (population 20,278), is a short 30-minute drive north from Portland, Maine's largest city. The businesses along its quaint Maine Street and the picturesque town centre cater to tourists in the summer and to the students of Bowdoin College the rest of the year.

The town's other major landmark is less well known. One of the locals working the 'Cool as a Moose' t-shirt shop one morning in 2014 characterized the vast swathes of asphalt and concrete just a few miles away as 'ghosty'.

She was referring to the Brunswick Naval Air Station (BNAS), once one of Maine's largest employers. But, after the Cold War ended, and the Soviet threat disappeared completely, the base's national security rationale did too. It closed officially in 2011. In the few years since, the community has adapted well, aided by a convenient location, good infrastructure and able management.

\subsection{The history of BNAS}

BNAS started as a modest airstrip in 1943, on 3,200 acres adjacent to Bowdoin's idyllic campus. Originally built as a training ground for British pilots learning to fly F4U Corsairs and F6F Hellcat airplanes, it was later used by US pilots for anti-submarine missions [21]. It never amounted to much, and seemed destined for obsolescence after the end of World War II.

The looming Cold War breathed new life into the base in the early 1950s. Brunswick was ideally situated to monitor Soviet submarines that might have threatened the Eastern Seaboard. For decades, residents and tourists driving up and down the main thoroughfare, U.S. Route 1, could see P-2 Neptunes and later P-3 Orions, propeller-driven planes with long tails that housed their submarine detection gear, cutting circles in the sky. In the summer of 1987, I spent a few days as a Navy midshipman with the men of VP-44. We flew P-3s low and slow over the Atlantic, and practised take offs and landings, but never did see any Soviet subs.

Brunswick wasn't the only facility that hosted P-3s, however, and the Navy repeatedly considered closing it [22]. US Senator Olympia Snowe and others in Maine's congressional delegation fought hard to prevent this from happening. They hadn't always been successful. 
The closure in 1994 of Loring Air Force Base in Limestone, Maine, had a devastating impact on the local economy [22]. A similar pattern would unfold, they feared, in Brunswick.

Not everyone in Maine felt that way. 'Bases are not jobs programs', noted an editorial in the Portland Press Herald in August 2001. 'They exist to defend the nation, and excess spending doesn't further that worthy goal' [24]. A little over a week later, another editorial in the same newspaper stressed that the mission that bases performed for national security were 'worth defending' but thought that the emphasis on 'the bases' economic impact ... [was] less persuasive' [25].

As it happened, the Navy sent mixed signals about BNAS's contribution to national security, and the economic impacts were unclear. Congress continued to allocate large sums for improvements on the base. Some hoped that such capital investment would boost the case for keeping the base open [26]. In the end, however, BNAS fell to the Base Realignment and Closure Commission's axe.

Some attempted an ultimately futile effort to reverse the commission's decision, but the local community turned to implementing its redevelopment plans. The town of Brunswick hired RKG Associates to help think through possible uses after closure. RKG reported in May 2005 that the loss of potentially 2,000 tenants or homeowners would deal a blow to the local housing market for five to ten years, but RKG's Craig Seymour urged the community not to panic [27]. 'There is an opportunity for success in redevelopment of the base .... It's a good piece of property. There is something for everyone there' [28].

\subsection{BNAS today}

It certainly seemed that way when I visited the offices of the Midcoast Regional Redevelopment Authority (MRRA) in July 2014. Vestiges of the old base were still clearly visible. The former gate house hadn't changed much, though it was occupied by bird houses as opposed to

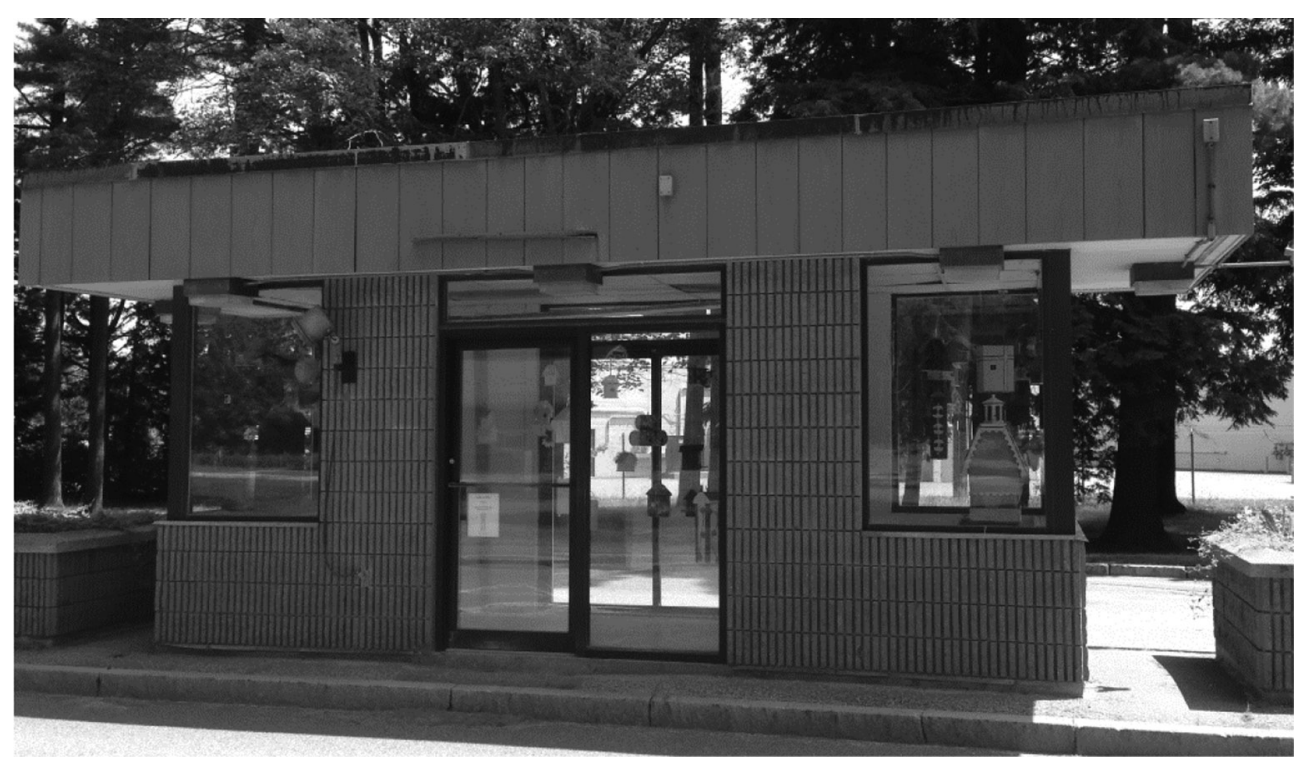

Figure 4: Former guardhouse at Brunswick Naval Air Station. Image by C. Preble. 
armed guards (see Fig. 4). A sign near the former on-base housing units advised no trespassing on Naval Air Station land. And the street names (e.g. Admiral Fitch Ave., Anchor Drive and Guadalcanal Street) betrayed the industrial park's naval heritage, if the static displays of P-2s and P-3s didn't give it all away.

But, for the most part, the base was looking ahead, not backwards. And its redevelopment had exceeded the most optimistic projections, even though the base had been in the agency's hands for barely four years. Jeffrey Jordan, Deputy Director of the MRRA, boasted during an interview in his office that they were 'blowing the doors off in a state that has anemic economic growth' [29].

They had benefited from several lucky breaks, but they also had a workable plan. Brunswick, Jordan noted, was a well-educated community, and there was overwhelming public participation in the planning process. Jordan also credited the members of the MRRA board, which included bankers, realtors and Maine's former chief economist. By law, elected officials were excluded from the 11-member board. John Richardson, a state legislator from Brunswick, and former speaker of the Maine House of Representatives, had crafted the legislation to ensure that the board was staffed by professionals, not politicians.

The facilities were in excellent condition, far better than at other comparable bases that had been closed around the same time. Given the uncertainty in the 1990s and early 2000s, the Navy had been reluctant to invest in a facility that might soon be closed. But repairs couldn't be postponed forever. In the base's final four years of operation, officials invested $\$ 150$ million in infrastructure.

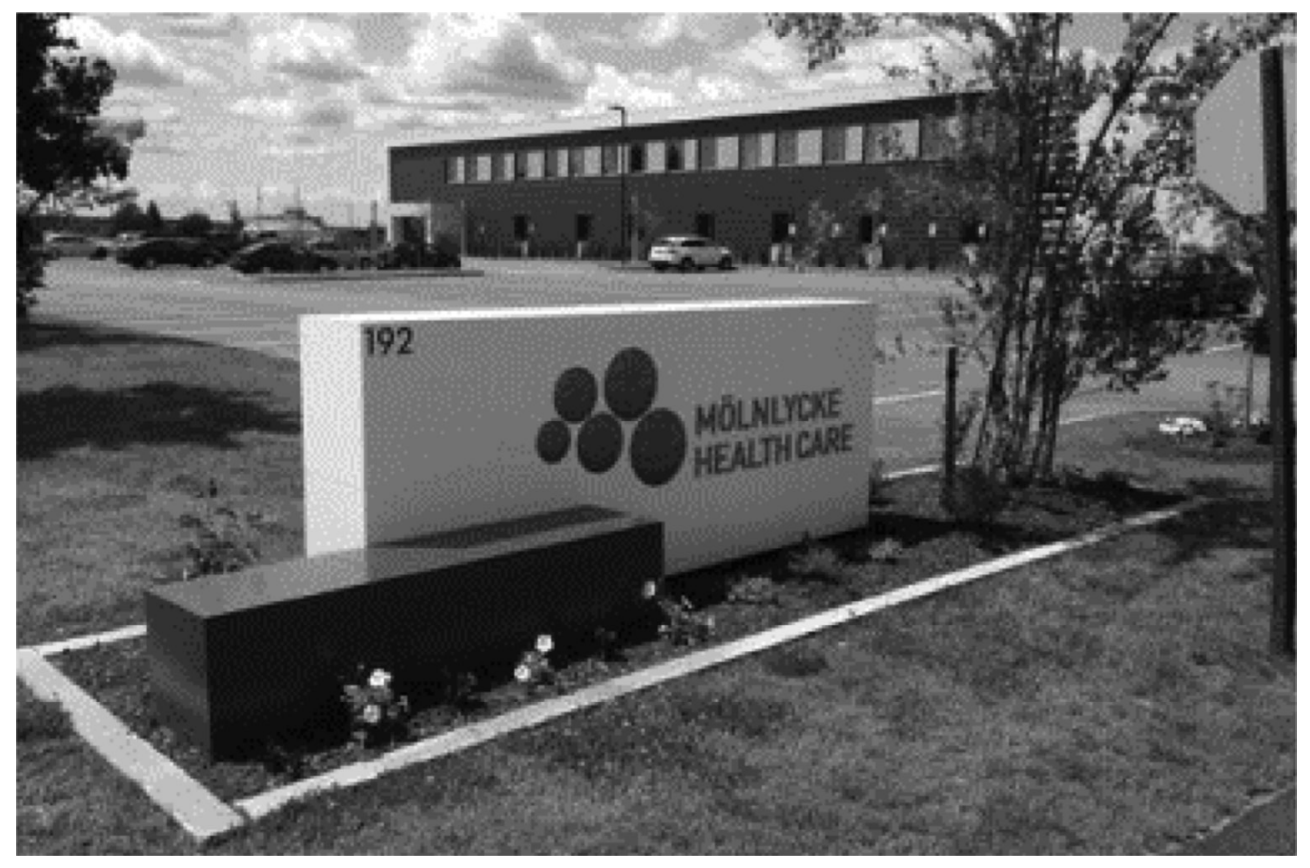

Figure 5: Swedish health care firm Mölnlycke's manufacturing facility at Brunswick Landing. Image by C. Preble. 
There was also considerable interest by private companies in the BNAS site. The Balfour Beatty realty group bought and sold the housing units. The Swedish company Mölnlycke, a maker of specialized bandages, was among the first to move into a new \$18 million building on the site (pictured in Fig. 5). And a new hotel that had been constructed to house visiting military personnel was to be converted to a retirement home.

Jordan, a former city manager of South Portland, was enthusiastic about the prospects for the former BNAS property, a city in its own right. He recognized that the redevelopment of such a vast tract of land was 'a marathon, not a sprint'. But, at the same time, he exulted: 'I'm having an absolute ball' [29].

\section{CONCLUSION}

Although the timing for redevelopment and reuse varies, all three properties have experienced a rebirth by transitioning to civilian uses.

Tredegar reminds us that not all military facilities are publicly owned, and therefore the defence conversion that occurred in Richmond was a private initiative, not a federal or state government one.

Today, the Springfield Technical Community College is a thriving, active campus, and the National Historic Landmark at Springfield, operated by the National Park Service, provides visitors with an overview of the Armory's work, and its historical significance. The Springfield Armory's lasting legacy may best be found not in the buildings left behind, but in the technical skills that it taught to generations of workers, many of whom took their talents elsewhere.

Lastly, in the case of the Brunswick Naval Air Station, a desirable property in a convenient location has swiftly adapted to multiple commercial and residential uses. It isn't too soon to call Brunswick a defence conversion success story.

\section{REFERENCES}

[1] DeCredico, M. \& Martinez, J.A., Richmond during the Civil War. Encyclopedia Virginia, 27 October 2015, available at http://www.encyclopediavirginia.org/Richmond_ During_the_Civil_War\#start_entry (accessed 29 March 2016).

[2] Hallerman, D., The Tredegar Iron Works: 1865-1876. Master's Theses. Paper 424, 1978, available at http://scholarship.richmond.edu/cgi/viewcontent.cgi? article=1427\& context=masters-theses (accessed 29 March 2016).

[3] Leveen, L., The other major Anderson. New York Times, 18 June 2011, available at http://opinionator.blogs.nytimes.com/2011/06/18/the-other-major-anderson/?_r=2 (accessed 29 March 2016).

[4] Virginia Department of Historic Resources, National Register of Historic Places Inventory - nomination form: Tredegar Iron Works, 1971, available at http://www.dhr. virginia.gov/registers/Cities/Richmond/127-0186_Tredegar_Iron_Works_1971_ NRHP_Final.pdf (accessed 9 September 2015).

[5] National Park Service, Tredegar Iron Works, available at http://www.nps.gov/nr/travel/ richmond/tredegar.html (accessed 8 September 2015).

[6] Squyres, T., The Tredegar logistical support in the American Civil War. Air War College Research Report, 1989, available at http://www.dtic.mil/dtic/tr/fulltext/u2/a217550.pdf (accessed 29 March 2016).

[7] Still Jr., W., Facilities for the construction of war vessels in the confederacy. The Journal of Southern History, 31(3), pp. 285-304, August 1965, DOI: 10.2307/2204441, available at http://www.jstor.org/stable/2204441. 
[8] Richmond Sentinel 1863, available at http://www.mdgorman.com/Written_Accounts/ Sentinel/1863/richmond_sentinel_12171863a.htm (accessed 30 December 2015).

[9] The Panic of 1873, American Experience. PBS, available at http://www.pbs.org/wgbh/ americanexperience/features/general-article/grant-panic/ (accessed 30 December 2015).

[10] NewMarket Corporation, Our History, available at http://www.newmarket.com/About/ Pages/OurHistory.aspx (accessed 8 September 2015).

[11] Hazelgrove, B., Email with Christopher Preble, 29 October 2015.

[12] Robertson, G.,Piecinghistory together.RichmondMagazine, 2014, available athttp://richmondmagazine.com/news/features/confederacy-and-civil-war-museums/ (accessed 14 September 2015).

[13] Richmond Riverfront Plan, City of Richmond, VA, 2012.

[14] MacKenzie, A., Springfield Armory, 2015.

[15] Kaufman, N., Conflicting Goals for a National Park: The Historic Arsenal at Springfield, 1968-2008, National Park Service, 2010.

[16] Raber, M., Malone, P., Gordon, R. \& Cooper, C., Conservative Innovators Military Small Arms: An Industrial History of the Springfield Armory, 1794-1968, Raber Associates, 1989.

[17] Raber, M., Conservative innovators, military small arms, and industrial history at Springfield Armory, 1794-1918. IA. The Journal of the Society for Industrial Archeology, 14, pp. 1-22, 1988.

[18] McNaughter, T., Marksmanship, McNamara, and the M16 Rifle: Organizations, Analysis and Weapons Acquisition. The Rand Paper Series, The Rand Corporation, Santa Monica, CA, p. 15, 1979.

[19] Garvey, E., President's Message. President's Five Year Report. S.T.C.C., 1972.

[20] Browne, L., Green, D., Benton, M., Chakrabarti, P., Kodrzycki, Y., Muñoz, A., Plasse, D. \& Walker, R., Towards a More Prosperous Springfield, Massachusetts: Project Introduction and Motivation, Federal Reserve Bank of Boston, 2009.

[21] Brunswick NAS, Cold War Relics, available at http://www.coldwarrelics.com/ brunswick_nas (accessed 30 December 2015).

[22] Wesel, L.M., Development Plans for BNAS Are Delayed. Portland Press Herald (ME), 18 July 1997.

[23] Cohen, T., Maine Senators Vow to Fight New Attempt to Close Bases. Portland Press Herald (ME), 30 June 2001.

[24] Editorial: Making Pentagon Efficient Calls for More Base Cutbacks. Portland Press Herald (ME), 5 August 2001.

[25] Maine's Military Bases Have Important Missions to Perform. Portland Press Herald, 14 August 2001.

[26] Cohen, T., P-3 Orion's New Home Might Help Save BNAS. Portland Press Herald (ME), 28 April 2003.

[27] Hoey, D., Impact of BNAS Closing Assessed. Portland Press Herald (ME), 14 April 2005.

[28] Hoey, D. \& Fish, J., Towns Taking Different Tack with Grants. Portland Press Herald (ME), 9 May 2005.

[29] Christopher Preble interview with Jeffrey Jordan, MRRA Offices. Brunswick, ME, 18 July 2014. 